\title{
ANALYSIS OF LIGHT POLLUTION AS A NEGLECTED ISSUE IN DEVELOPMENT
}

\author{
Rika Isnarti \\ International Relations Department \\ Faculty of Communication and Diplomacy \\ Universitas Pertamina \\ Email: rika.isnart@universitaspertamina.ac.id
}

\begin{abstract}
The growth of economy that encourage development sometimes cause damage to environment. One of the case is light pollution while many people do not realize this pollution is existed. This research analyses light as one kind of pollution that people tend to unrealize. It describes cause and effect of light pollution. This pollution occurs because overused and misdirected light. Moreover, economics growth and increasing of population encourage this phenomena. Further, It argues that light pollution gives bad impact to environment and animal as well as becomes a threat to human health. This research employs qualitative methods by collecting, categorizing data from library research. It found that light pollution give bad impact to environment and human health, such as miss direction in migration animals, we cannot see Milky Way, and potential breast cancer to human. In addition, light pollution also wastes of energy. So, more attention has to be paid to this pollution and several managements in development and regulation have to be taken to manage this pollution worse.
\end{abstract}

Keywords: environment, development, light, pollution, sustainable

\begin{abstract}
ABSTRAK
Pertumbuhan ekonomi yang mendorong pembangunan terkadang menyebabkan kerusakan lingkungan. Salah satu kasusnya adalah polusi cahaya yang berasal dari penggunaan lampu. Sementara, banyak orang tidak menyadari polusi ini ada. Penelitian ini menganalisis penggunaan cahaya lampu yang berlebihan sebagai salah satu jenis polusi yang cenderung tidak disadari orang. Tulisan ini memaparkan penyebab dan efek dari polusi cahaya. Lebih jauh lagi, Penulis menemukan bahwa polusi cahaya memberi dampak buruk bagi lingkungan dan hewan serta menjadi ancaman bagi kesehatan manusia. Penelitian ini menggunakan metode kualitatif dengan mengumpulkan data dari perpustakaan penelitian. Polusi cahay lampu ini terjadi karena cahaya yang digunakan secara berlebihan dan salah arah. Selain itu, pertumbuhan ekonomi dan peningkatan populasi mendorong fenomena ini. Penelitian ini juga menemukan bahwa polusi cahaya memiliki dampak negatif pada lingkungan dan kesehatan manusia, seperti kehilangan arah pada hewan migrasi, manusia tidak dapat melihat Bima Sakti pada malam hari, dan potensi kanker payudara pada manusia. Selain itu, polusi cahaya juga membuang energi. Jadi, lebih banyak perhatian harus diberikan pada polusi ini dan beberapa manajemen dalam pengembangan dan regulasi harus diambil untuk
\end{abstract}


mengelola polusi ini agar tidak memburuk.

Kata Kunci: Cahaya, keberlanjutan, Lingkungan, Pembangunan, Polusi

\section{INTRODUCTION}

Many aspects of our life do not sustain the environment while we develop. One of them is lights. This paper examines light pollution as a neglected issue in sustainable development. We need light for security and improve visibility, for instance, traffic light and bulb at home. However, the growth of economics made people overused light and misdirected it. Besides, economics growth creates people to overuse light, and it also wastes energy. As a result, light pollution occurs.

To achieve sustainable development, we require to sustain the environment as economic growth. Economics growth without maintaining the environment could not be categorized as sustainable development. Economics and population are two common factors that contribute to light pollution while the effects are on human health and the environment generally. There are many shreds of evidence that economic activity and urban density are correlated with the existence of light pollution. (Gallaway, 2010).

In addition, not too many people realize this issue as one of the developmental issues. Many people ignore the potential of light pollution that could threaten our health and the fact that it is caused by economic growth because light pollution does not cause tremendous effect in the short term. Some of the impacts of light pollution are that we cannot see Milky Way in the night sky and cancer potential to humans (Gallaway, 2010 p.658). Even though light pollution impacts biodiversity and environment, for instance, misdirection migration of birds, Female Physalaemus pustulosus frogs are less selective about mate choice when light levels are increased (Longcore, 2004. P. 194). This essay focuses more on human health impact than biodiversity.

This essay aims to justify light pollution as a neglected aspect of development, which has numerous effects on both people and the environment, to describe what effect on human health caused by light pollution, to discuss the economic and technological development in managing light pollution and government regulation. So, more attention needs to be paid to 
this issue and manage sustainable economic to cause a worse condition of light pollution.

This essay traces some academic research projects talking about light pollution to justify its aim. Several previous research projects talking about economic and light pollution relations and their impact on human health are taken and analyzed. One of the raw research data used as a reference in this paper is from remote sensing data from satellite observations Defense Meteorological Satellite Program (DMSP) Operational Linescan System (OLS). Finally, this research gives a map measurement of economic activity, real per capita GDP, also statistically significant impacts on levels of light pollution combine with increasing the percentages of the population living in light pollution in a country. (Gallaway, 2010 p. 660). It also includes data from the light pollution conference, which is produced in its handbook about light pollution to be used in this essay. Moreover, the relation between economic and human health in sustainable development studies also used as literature. All of them analyse and elaborate to show the existence of light pollution in this paper.

\section{ANALYSIS AND RESULTS}

\section{How Light Pollution Occurred}

Light pollution has been occurred since 1990s, indicated by an increasing concern outdoor lighting (Tural, 2006,p. 775). Many countries used too many lights not only for security purposes but also for beautification purposes. For instance used light for advertisement and city beautification programs of the cultural and architectural assets of the city. As a result, light pollution occurs because light becomes overused. The purpose of light move from security to design used artificial light, while this artificial light give negative impact. In addition, although light emissions have increased, only small attention has been paid to light pollution, if we compared with other forms of pollution (Lyytimaki, 2012 p. 599).

Light pollution is brighter light that is not aim for a particular reason but named for security purposes and waste energy because shine upward into space and not use for specific aim. It causes glare, or deepens shadows, washes out the stars and reduces visibility. This mostly comes from the advertising of gas stations, convenience stores, and shopping centers 
light, architectural assets, decorative and garden lighting, sport field, street lighting, residential out lighting, fishing boats, security lights, lights on vehicles, and even lights on undersea research vessels. The effect of light pollution are unsafe glare to drivers and pedestrians, harms the biological integrity of ecosystems, causes light to trespass into homes and bedrooms, creates sky glow above cities, uncomfortable to the human eye, and psychological and physiological effects on human health, and is a source of environmental degradation (Elliot, 2006 p. 260).

Although at the beginning the purpose of using light is good to secure, at the end it causes bad impact. Several cases show that, there is no correlation between security and light. One research did by Cooke (2005 p. 10) indicated that young women at brightly bus shelters at night feel exposed and prefer stand discretely in the shadows to prevent from criminal action. Furthermore, a criminal using a torch is more likely suspicion than someone wandering around in an over lit area. Of course we need light to show our road ways. However, misplaced and over bright light in road ways can distract and confuse us. The glare create from over brighter light impair our visibility as a result, we cannot drive and walk safely in the roads.

Another example why light comes into pollution is a neon lights might improve our visibility. However, if we use a thousand neon light everywhere will reduce our visibility sign. It happens because light reflection spills outside the area it is meant and create light trespass and sky glow. Consequently, this misdirected, overused, badly and poorly light contribute to waste energy because increase carbon dioxide emission (cooke,2005,p.5). Besides, in a big scale it effects human and environment damage.

Light pollution does substantial damage from wildlife to human health. Light pollution disrupts feeding, reproduction, sleeping and migration of birds, fish, insects and plants. It can be concluded that our aim to protect from night with light becomes misdirection or cause another problem while we overused it.

\section{Economics and Population Contribution in Light Pollution}

In previous part we know how light pollution occur technically. Furthermore, light pollution is one of developmental problems. Gallaway (2010, p. 662) in his research believes 
that light pollution is concentrated in areas with high levels of population and that surface area measures of light pollution are also affected by economic development. In his research also indicated that there is a correlation between light pollution and increase of Gross Domestic Product (GDP).

It can be seen that in economically developing regions, particularly in Newly Industrialized Countries (NICs) such as China and India, electric lighting is likely to continue to increase significantly (Gaston, 2012 p. 1260). This happens because many sectors have to be built without considering environment protection. To see how development in infrastructure contribute to light pollution we can see several examples below. In China, the percentage of roads that are paved is a rough indicator of the level of infrastructure development. Paved roads promote economic development of the hinterland (Gallaway,2009p.662). However, this also brings negative impact to environment because government also need to complete road with light. Badly and poorly light design caused light pollution. The more road build, bigger chance to a country get light pollution if they do not consider the light design environmentally.

Sometimes, in build roads a country needs to build bridge to link between two areas and install many bulbs with two purposes security and beauty. However, this second purpose being dominant. It is also a prestigious or a proud if an area has beautiful architecture with many bulbs installation and shine at night. In fact, this action brings a negative impact. Too bright at an area will dark the sky and we cannot see the stars up the sky. Although it looks simple but the impact astronaut cannot see galaxies, nebulae, and other celestial objects. As a related matter, light pollution does tremendous damage to a unique scenic resource. The growth and development in coastal area encouraging to build new infrastructure for tourism sector also support for light pollution. Touristic development driven using of artificial light to enhanced the beauty of that area.

The globalization of commerce and industry may also have impacts on light pollution. Increasing flows of investment necessarily contributes fully to the economy of that country (Doll, 2006 p. 90) as a result, in developing countries many industrial complex are built. These building install many bulbs, because they need to operate 24 hours. Moreover, they also use 
ever brighter light to support production. For instance in garment fabric they need to install and turn on light within a full day to support fabric production in the afternoon so their worker can work properly and at night for security reason. Though this activity support people livelihood in developing country while they can get a job but work behind a light is not good for healthy reason and create light glare, trespass and sky glow at the night.

Furthermore, light pollution does not only occur because of development but also to achieve livelihood. For example fisherman catch fish using light but caused degradation of the photic habitat in the sea by artificial light (Gaston, 2012). Light pollution occurs when organisms are exposed to light in the wrong place, at the wrong time or at the wrong intensity. As a result, light pollution inhibits growing plant and cyclus in the sea.

Globally, light pollution increases at $6 \%$ per year both developing countries and many in developed countries (Gallaway, 2010 p. 673). In developing countries light pollution increases because expansion of road, build many industries, use too many advertisement broad, and unenvironmetally livelihood practice. On the other hand, in developed countries light pollution mostly is from beautification. For example use brighter light in monument in the city, in architectural building and bridge, use light in home and garden.

One of the research did by Gallaway (2010) in mapping light pollution indicated that in coastal areas, where many of major cities such as Mumbai, Shanghai, Alexandria, Miami, New York City and London are located, long stretches of the shoreline are strongly illuminated from glamorous building but only little from house light outdoor. Light pollution is concentrated precisely because populations are concentrated. Moreover, this concentration tends to be along coastal areas, which can often be ecologically important and in urban area (Gallaway,2010 p. 660). However, in developing countries in Africa, and Asia most of light are from industrial fabric, household and road paved. Indeed the cores of urban centers are bathed in light and the resulting light pollution can extend more than a hundred kilometers out from the city's edge.

Looking at the changing population dynamics over the next generation is that virtually all of the two and half billion new citizens of our World will live in small and medium sized cities within emerging economies. Thus, while mega cities continue in their dominant 
position, more modest sized cities will serve as the true future centers of growth. This means that artificial light will not only continue to intensify with population growth, but that the number of locations of high intensity light pollution will also increase dramatically. Even in areas where total population growth is low, such as in the developed countries, analysis suggests that the environmental influences of night light will continue to spread.

Considering the effect of light pollution, greater attention seems likely to be paid in coming years to reducing light trespass on the grounds that it represents a costly loss of lighting to areas in which it is not wanted. The proper use and color of indoor and outdoor lighting is important to the health of both humans and ecosystems. Lighting fixtures should be designed to minimize interference with normal circadian rhythms in plants and animals (Pauley, 2004, p.1)

\section{Light Pollution Impacts to Human Health and Environment}

Light pollution can affect animals and plants, especially their biodiversity while human can be threaten of health such as breast cancer. In the sea, the behavior, reproduction and survival of marine invertebrates, amphibians, fish and birds have been shown to be influenced by artificial lights (Gallaway, 2010 p. 674). These effects arise from changes in orientation, disorientation and attraction or repulsion from altered light environments (Longcore 2004)

In Victoria, experience in the specific case of upwardly directed flood lighting of trees is that ring tail and brush tail possums both become disoriented by the upwards pointing lights and stare at them with consequent temporary loss of vision.(Cooke,2005 p. 5)

Various research studies demonstrate the impact of light pollution on human health. Light pollution as developmental problem impact human health in two ways. First, light used in outdoor impact security, human health cancer and others. Second it changes human life for example in working shift when people have to work at night behind the light. The suppression of melatonin by exposure to light at night is closely related to higher rates of breast and colorectal cancers (Falchi, 2011 p.2719). Moreover, the negative effects on the human circadian clock due to the relationship between the blue light sensitive retinal ganglion cell light receptors and the modern high-intensity discharge and white LED lamps (Rabaza, 2010, 
p.1) Exposure to light at night disrupts the body's circadian rhythms and suppresses nocturnal production of the hormone melatonin. Asan antioxidant, in many studies melatonin has been shown to protect DNA from oxidative damage. Once damaged, DNA may mutate and carcinogenesis may occur (Cooke, 2005, p. 8).

Besides light pollution obstruct human from sleep and shadow in the road. In this modern world we often work behind the light. In the industrialized country, much of the daytime work force is exposed to dim office lighting instead of bright sunlight and at night worker are often exposed to bright lights with blue wavelengths instead of natural darkness. Some researchers believe that without a normal cycle inhibition and production responding to cycles of light and dark, human health may be negatively affected (Pauley, 2004. P.590)

The electric light is the hallmark of modern life in the industrialized world and could possibly be linked to the higher rates of breast cancer. Recent epidemiological studies of night shift worker populations show higher rates of breast cancer ranging from $36 \%$ to $60 \%$ among women worker in developing countries India, China, Vietnam, Indonesia. (Falchi, 2011 p.2714) In developing countries about 40,000 women die each year from breast cancer. Richard (2011) noted that breast cancer rates are three to five times lower in developed country while not too many worker work in night shift.

Another impact of light pollution is light pollution wastes energy. This is about $50 \%$ of light up into the sky where serves no useful purpose (Narisada, 2004). Most of this light use for beauty and overused that create carbon emission. If we need light for visibility and security one light and core direction is enough. However, people think one neon light is not enough and turn many bulbs on. It can be seen that people turn on bulbs in garden, in swimming pool, in bridge, skyscraper building and many more to show its beauty. Replacement of such lights with a better designed fitting would allow the use of lower power lamps to give the same degree of illumination thus halving their running costs. This benefits the owner of the light while at the same Time reducing the light polluting effect. This is a win-win situation for all concerned.

Of course, we need energy to produce electricity but half of this energy waste to the sky and give drawback. As a result, this light reflection obstruct the visibility to the sky and reduce 
our energy saving. More consequently, we are in the earth cannot see the stars while astronaut cannot see nebulae and other because earth are brighter and it is difficult for them to predict whether it is a star of light from the earth. In America only $40 \%$ live in sufficiently dark at night for the human eye to make a complete transition from cone to rod vision. In astronomical standards only $18.7 \%$ of the terrestrial surface of the Earth is allowed exposed to night sky brightness (Longcore, 2005, p. 192)

\section{Light Pollution Management}

Light pollution has to be managed in order to reduce its effect. Reducing light trespass may not only reduce the ecological impacts and human health of artificial light, but also has economic cost saving. We need to understand and realize this issue so adequate technology to create better artificial light for human utility and development can be taken to solve this pollution.

Government needs to formulate rules to control light and trespass both internationally and nationally. There are many countries have been implemented rules to control light. Australia has Australian Standard AS4282 -1997 to control of the obtrusive effects of Outdoor Lighting for determining intrusive nuisance resulting from the glare effects of outdoor. (Cooke, 2005, p. 14)

Success and implementation most of these prescriptions are already implemented in some of the most advanced anti-light- pollution laws such as in the UK, there is The Environmental Protection Act 1990 that control energy safety from light, nuisance and other. In Japan the government creates light pollution handbook for their people as a guidance to install bulb at home. Lombardia (Italy) Regional Law n.17 of March 27, 2000 regulates several things such as Eliminate Over lighting: Avoid luminance or illuminances greater than the minimum required for the task, and dim lights, shut off lights when not in use turn the lights off when you the room, or for the lights to turn off automatically, but in outdoor lighting these options are rarely available, almost all the parking lots of shopping malls are lit all night long, and likewise for the industrial/artisan/commercial areas, whether or not there are workers at night. 
Falchi (2011) found in Lombardia, the artificial sky brightness did not increase over the last twelve years. This is probably due to the adoption of laws against light pollution in the surroundings of the sites. A full enforcement of the prescriptions could probably make a substantial improvement in the quality of the night sky and environment.

There are many other ways that can be taken to reduce light pollution effect. Maintaining and increasing natural unlit areas is likely to be the most effective option for reducing light pollution. It can be done by decreasing the duration and intensity of lighting. Going down the light duration will reduce energy costs and carbon emissions. People need to control light time when and what time we have to turn light on because we also need dark. Decreasing the intensity of lighting will limit both sky glow and the area impacted by high intensity direct light. Simple way to apply this concept is using the artificial lights cape with whiter light. This artificial light type will give light illumination correctly and drive for more cost effective low carbon street lighting solutions and growth in the artificially lit area. As we know the common factor caused light pollution is misdirect and overused. Flexible control systems in light road, including on-demand street lighting, may be useful tools. It will provide dark period but can be shine when needed.

Even though many countries around the world have paid attention to light pollution. There are still limitation to tackle this problem. There is no fix regulation to control about this pollution especially in international level. Many countries that have regulation about it do not have enough effective regulation and not all of their citizen know about it. Moreover, light pollution is quite difficult to manage because not to many people realize about this issue and this issue also over sided with social and economic problem. When we try to control light pollution there is other social economic problem have to be sacrifice. For instance. In beautification and development in tourism sector. While reduce the amount of light could be decrease the sense of beauty in one area and reduce its tourism value. Furthermore, some people feel more comfort in an area that illuminate very well. They do not like their house in dark and prefer to install many bulbs.

\section{CONCLUSION}

Light pollution is one of development problem and need to pay attention because it 
caused of economic growth and population and give numerous effect to people and environment. This pollution occurred because of development infrastructure in developing country and use light for security purposes. However, because bad and poor design light becomes pollution. In developed country, light changes into pollution because overused light to beauty objective. Light use to see monument, architecture, garden and other in the city to show its beauty while this actions actually overused and misdirected light. This phenomena wastes energy and create carbon emission. Further impacts are human health in cancer, change in human cyclus while people have to work at night and face sky glow and trespass. Light pollution also impact to biodiversity. Several prevention steps need to be taken to reduce more effect in the future. Several countries have implemented regulation related light. Realization about this phenomena is also important to reduce further effect on light pollution. Moreover, people need to decrease intensity and light duration. Development in technological also needed to produce best environmentally light. Further research about light pollution need to be taken for example to what extent economy growth influence light pollution and how to manage limitation from manage light pollution.

\section{REFERENCES}

Baumgärtner, S. \& Quaas, M. 2010. What is sustainability economics? Ecological Economics, $69,445-450$.

Cooke, K. 2005. Light Pollution, A Growing Environmental, Safety And Health Hazard For Residents Of Strathfield. Strathfield Vision.

Depledge, M. H., Godard-Codding, C. A. J. \& Bowen, R. E. 2010. Light Pollution In The Sea. Marine Pollution Bulletin, 60, 1383-1385.

Doll, C. N. H., Muller, J.-P. \& Morley, J. G. 2006. Mapping Regional Economic Activity From Night-Time Light Satellite Imagery. Ecological Economics, 57, 75-92.

Elliott, P., Rich, C. \& T, L. 2006. Ecological Consequences Of Artificial Night Lighting. Biological Conservation, 132, 275.

Falchi, F., Cinzano, P., Elvidge, C. D., Keith, D. M. \& Haim, A. 2011. Limiting The Impact Of Light Pollution On Human Health, Environment And Stellar Visibility. Journal Of Environmental Management, 92, 2714-2722.

Gallaway, T., Olsen, R. N. \& Mitchell, D. M. 2010. The Economics Of Global Light Pollution. Ecological Economics, 69, 658-665. 
Gaston, K. J., Davies, T. W., Bennie, J. \& Hopkins, J. 2012. Reducing The Ecological Consequences Of Night-Time Light Pollution: Options And Developments. Applied Ecology, 49, 1256-1266.

Hettige, H., Mani, M. \& Wheeler, D. 2000. Industrial Pollution In Economic Development: The Environmental Kuznets Curve Revisited. Journal Of Development Economics, $62,445-476$.

Horváth, G., Kriska, G., Malik, P. \& Robertson, B. 2009. Polarized Light Pollution: A New Kind Of Ecological Photopollution. Front Ecological Environment, 7, 317-325.

Kocifaj, M. \& Aubé, M. 2014. Light Pollution: Theory, Modeling, And Measurements. Journal Of Quantitative Spectroscopy And Radiative Transfer, 139, 1-2.

Longcore, T. \& Rich, C. 2004. Ecological Light Pollution. Front Ecological Environment, 2, 191-194.

Lyytimäki, J., Tapio, P. \& Assmuth, T. 2012. Unawareness In Environmental Protection: The Case Of Light Pollution From Traffic. Land Use Policy, 29, 598-604.

Mizon, B. 2002. Light Pollution Responses And Remedies, New York, Spriger.

Narisada, K. \& Schreuder, D. 2004. Light Pollution Handbook, Netherlands, Springer.

Pauley, S. M. 2004. Lighting For The Human Circadian Clock: Recent Research Indicates That Lighting Has Become A Public Health Issue. Medical Hypotheses, 63, 588-596.

Pollard, N. Lighting In The Countryside Light Pollution: The Global View. In: Schwarz, H. E., Ed. International Conference On Light Pollution, 2002 Chile. Spirnger Science, 135-144.

Rabaza, O., Galadí-Enríquez, D., Estrella, A. E. \& Dols, F. A. 2010. All-Sky Brightness Monitoring Of Light Pollution With Astronomical Methods. Journal Of Environmental Management, 91, 1278-1287.

Schwarz, H. E. 2002. Light Pollution: The Global View, La Serena, Chile, Springer Science.

Settele, J. 2009. Ecologists Should Join Astronomers To Oppose Light Pollution. Nature, 457, 379-379.

Stone, E. L., Jones, G. \& Harris, S. 2009. Street Lighting Disturbs Commuting Bats. Current Biology, 19, 1123-1127.

Takagi, M. \& Gyokusen, K. 2004. Light And Atmospheric Pollution Affect Photosynthesis Of Street Trees In Urban Environments. Urban Forestry \& Urban Greening, 2, 167-171.

Tural, M. \& Yener, C. 2006. Lighting Monuments: Reflections On Outdoor Lighting And Environmental Appraisal. Building And Environment, 41, 775-782. 